\title{
Three new species of South American Moraceae
}

\author{
C.C. Berg $^{1}$, J. Homeier ${ }^{2}$
}

Key words

Ficus

Helicostylis

Moraceae

Naucleopsis

new species

South America
Abstract New South American species are described, one in each of the following genera: Ficus, Helicostylis and Naucleopsis.

Published on 20 August 2010

\section{INTRODUCTION}

The species described in the present paper have been mentioned in previous publications (Berg 2001, Berg \& Villavicenco 2003,2004 ) as unnamed collections, because of insufficient material for a proper description or uncertainty about distinctness.

\section{Ficus machupicchuensis C.C.Berg, sp. nov. - Fig. 1}

Fico boliviana similis, ficis minutis sessilibus, ostiolo sine ora 3-lobata differt. - Typus: I. Huamantupa, Y. Guttierez \& E. Quispe 3914 (holo USM; iso BG, and according to TROPICOS also: AMAZ, CUZ, HUT, MO and MOL), Peru, Cusco, Prov. Urubamba, Machu Picchu, 2500 m, 25 Nov. 2003.

Tree to $30 \mathrm{~m}$ tall. Leafy twigs $2-5 \mathrm{~mm}$ thick, glabrous or (minutely) white-puberulous; periderm \pm flaking off. Lamina (sub)coriaceous, elliptic to oblong, $5-16(-21)$ by $2.5-7(-8.5)$ $\mathrm{cm}$, base rounded to cuneate or to subcordate, apex (short-) acuminate to acute; upper surface glabrous or sparsely whitepuberulous on the midrib, lower surface white-puberulous on the veins or glabrous; lateral veins (8-)10-15 pairs, the basal pair weak and short, up to $1 / 20-1 / 10$ the length of the lamina, unbranched, tertiary venation reticulate; petiole $1-2.7(-4.5) \mathrm{cm}$ long, 1-2 mm thick, glabrous or (minutely) white-puberulous; stipules 1-2.8 cm long, white-puberulous, mainly in the lower part and on the keel or glabrous outside, glabrous inside, caducous. Figs axillary, in pairs or solitary, sessile; basal bracts 4-5 mm long, minutely white-puberulous outside, glabrous inside, receptacle depressed-globose (to subglobose), 0.6-0.7 $\mathrm{cm}$ diam when dry, with rather dense brown pluricellular submicroscopic trichomes, colour at maturity unknown, ostiole c. $2 \mathrm{~mm}$ diam, flat, closed by (2 or) 3 bracts, these sparsely minutely white-appressed-puberulous; internal hairs absent. Staminate flowers to $0.5 \mathrm{~mm}$ long pedicellate; tepals 3 , c. 1 $\mathrm{mm}$ long; stamen 1, anther c. $0.6 \mathrm{~mm}$ long. Pistillate flowers: tepals 3, 0.8-1.2 mm long; stigma bifid; long-styled flowers, sessile; style c. $1 \mathrm{~mm}$ long; short-styled flowers to $0.5 \mathrm{~mm}$ long

\footnotetext{
${ }^{1}$ Bergen Museum, University of Bergen, Allégate 41, 5007 Bergen, Norway; Netherlands Centre for Biodiversity Naturalis (section NHN), Leiden University, P.O. Box 9514, 2300 RA Leiden, The Netherlands; corresponding author e-mail: berg@nhn.leidenuniv.nl.

${ }^{2}$ Albrecht-von Haller Institut für Pflanzenwissenschaften, Georg-August Universität, Untere Karspüle 2, D-37073 Göttingen, Germany; e-mail: jhomeier@gwdg.de.
}

pedicellate; style c. $0.5 \mathrm{~mm}$ long. Interfloral bracts numerous, 0.8-1.2 mm long.

Distribution - Peru (Cusco) and Bolivia (Santa Cruz); in montane forest, altitude 1400-2400 m.

Notes - 1. This species shows affinities to lowland species F. boliviana C.C.Berg (1999) in its vegetative parts, but the figs are clearly different, being small, sessile and without the distinctive 3-lobed rim around the ostiole.

2. The two collections from Cusco are more clearly hairy than those from Bolivia.

3. The species resembles the occasional material of $F$. cervantesiana Standl. \& L.O.Williams without the characteristic hairs on the midrib of the lamina beneath, from which the new species differs in the short-acuminate to acute apex of the lamina (whereas distinctly acuminate in F. cervantesiana), and the flat ostiole (being \pm prominent in $F$. cervantesiana) and in the relatively short stipules, to $2.8 \mathrm{~cm}$ long, whereas mostly 3-4 cm long in F. cervantesiana.

Additional specimens examined. BoLIVIA, J. Balcazar et al. 749 (BG, USZ), 2100 m, 3 July 1996 (st); M. Saldias et al. 4282 (BG, USZ), Santa Cruz, Prov. Florida, Santa Rosa 1470 m, 1 July 1996 (st). —Peru, P. Núñez 9876 (BG), Peru, Cusco, Prov. Urubamba, rd. Pampacahua-Pachachaca, km 107, Machu Picchu, 2380 m, 21-28 Sept. 1988 (st).

\section{Helicostylis salicifolia C.C.Berg, sp. nov. - Fig. 2}

Helicostylidi tovarensi similis, petiolis et inflorescentiarum staminatarum miniorum pedunculis brevioribus, venatione tertiaria sati obscura differt. - Typus: I. Sánchez, M. Dillon \& M. Zapata 9456 (holo F; iso BG), Peru, San Martín, Prov. Rioja, Distr. Pardo Miguel, between Aguas Verdes and road to San Pablo, 1220 m, 23 June 1998 (male).

Shrub up to $2 \mathrm{~m}$ tall. Leafy twigs 1-2 mm thick, rather sparsely whitish- to yellowish-puberulous. Leaves (on lateral branch) distichous; lamina lanceolate, $2.5-6$ by $0.5-1.2 \mathrm{~cm}$, apex subacuminate, acumen apiculate, base cuneate, margin entire; upper surface whitish- to yellowish-puberulous on the midrib, lower surface whitish- to yellowish-appressed-puberulous on the main veins, minutely patent-puberulous on the smaller veins; midrib impressed above, venation slightly prominent, the smaller veins almost flat beneath, lateral veins $6-9$ pairs, tertiary venation reticulate; petiole $2-3 \mathrm{~mm}$ long, c. $0.5 \mathrm{~mm}$ thick, sparsely whitish- to yellowish-puberulous; stipules lateral, 2-5 $\mathrm{mm}$ long, yellowish appressed puberulous to subsericeous to subglabrous. Staminate inflorescences axillary, solitary or pairs, 


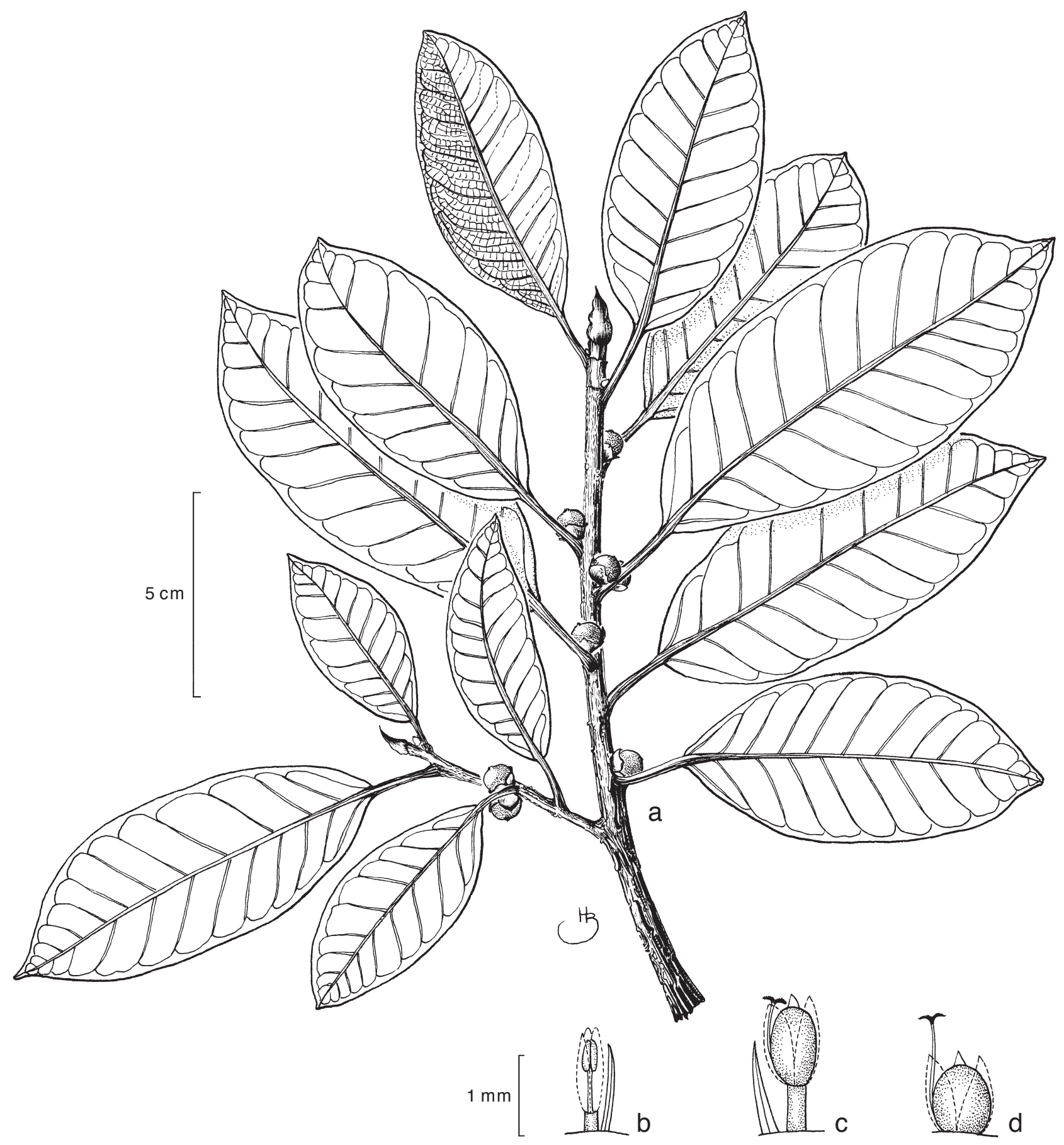

Fig. 1 Ficus machupicchuensis C.C.Berg. a. Leafy twigs with figs; b. staminate flower and interfloral bract; c. short-styled flower with interfloral bracts; d. long-styled pistillate flower (all: Huamantupa et al. 3914, BG). — Drawing by Hendrieke Berg (Voss).

c. $3 \mathrm{~mm}$ diam; peduncle 1-2 $\mathrm{mm}$ long, receptacle c. $1.5-2$ $\mathrm{mm}$ diam; involucral bracts in $2-3$ series, ovate, $1.5-2.5 \mathrm{~mm}$ long, whitish appressed-puberulous; flowers c. 10-20; perianth c. $1 \mathrm{~mm}$ long, tepals subdecussate, two by two slightly different, (sub)cucullate, the margin ciliolate with crinkled hairs; stamens 4, about equal, filaments c. $2.5 \mathrm{~mm}$ long, anthers c. $0.6 \mathrm{~mm}$ long, not apiculate.

Distribution - The species is only known from the type collection made in evergreen forest.

Note - In Berg 2001 (p. 369), this collection has been mentioned under Helicostylis tovarensis and considered to be distinct at the subspecific level. Even without obtaining additional material with pistillate inflorescences the collection shows sufficient differentiating characters to describe it as new species. Such characters are the shorter petiole and peduncle, the smaller staminate inflorescence and flower, and the rather obscure tertiary venation. The frutescent habit may be an additional distinctive character.

\section{Naucleopsis francisci C.C.Berg \& Homeier, sp. nov.} - Fig. 3

Naucleopsidi ulei similis, infrutescentibus tepalis parte libera multo breviore, inflorescentium staminatarum pedunculis ebractetis differt. - Typus: $B$. Merino et al. 4504 (holo LOJA; iso BG), Ecuador, Loja, Parque Nacional Podocarpus, road Loja-Zamora, San Francisco, 2100 m, 4 May 1995 (fr).

Tree $20 \mathrm{~m}$ tall. Leafy twigs $4-5 \mathrm{~mm}$ thick, whitish puberulous; periderm flaking off. Leaves laxely spirally arranged to distichous; lamina lanceolate $10-30$ by $3.5-7 \mathrm{~cm}$, apex acuminate, base obtuse, margin entire \pm revolute, upper surface glabrous, 


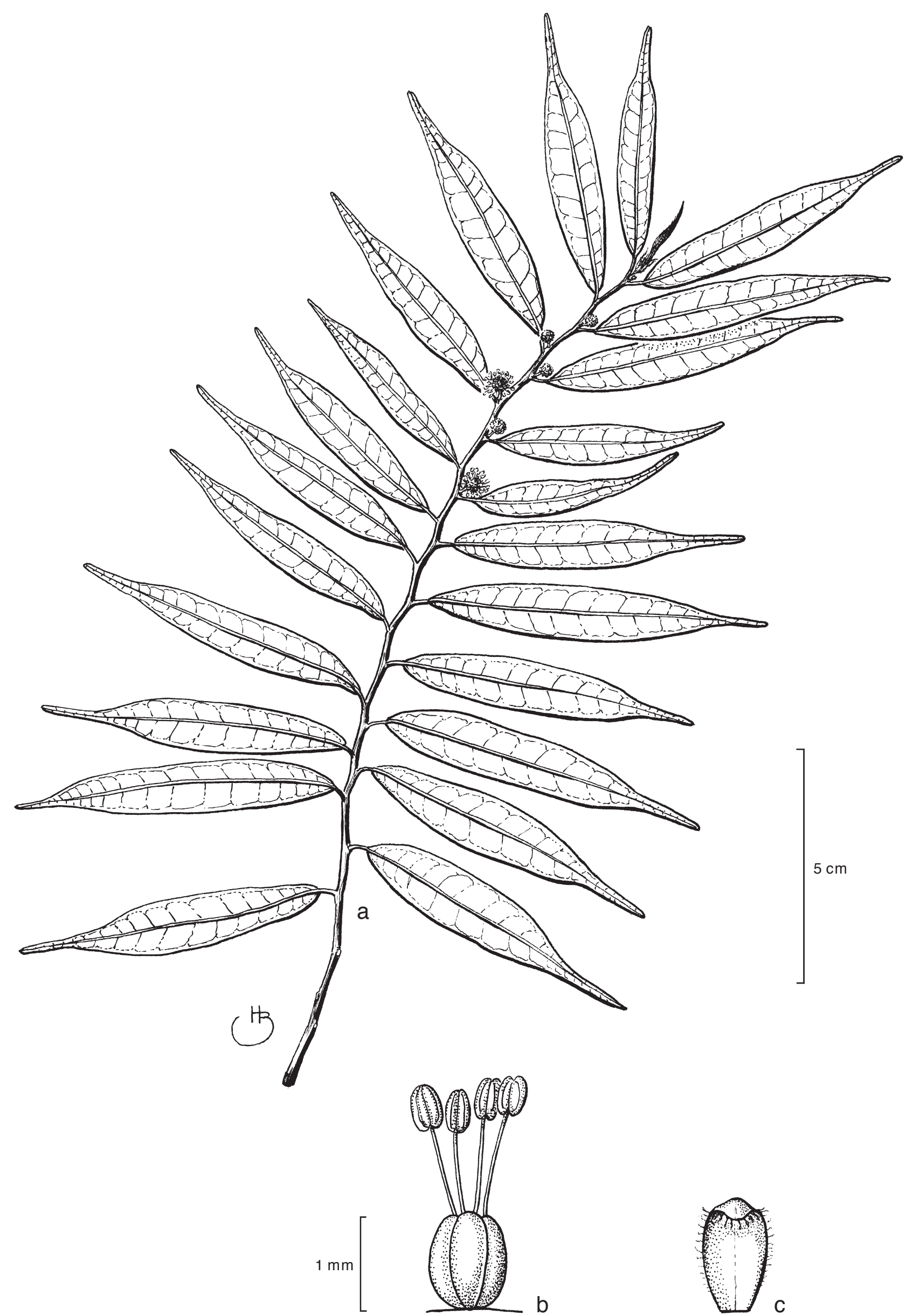

Fig. 2 Helicostylis salicifolia C.C.Berg. a. Leafy twig with staminate inflorescences; b. staminate flower; c. tepal (all: Sánchez et al. 9456, BG). - Drawing by Hendrieke Berg (Voss). 
C.C. Berg \& J. Homelier: Three new species of Moraceae

199

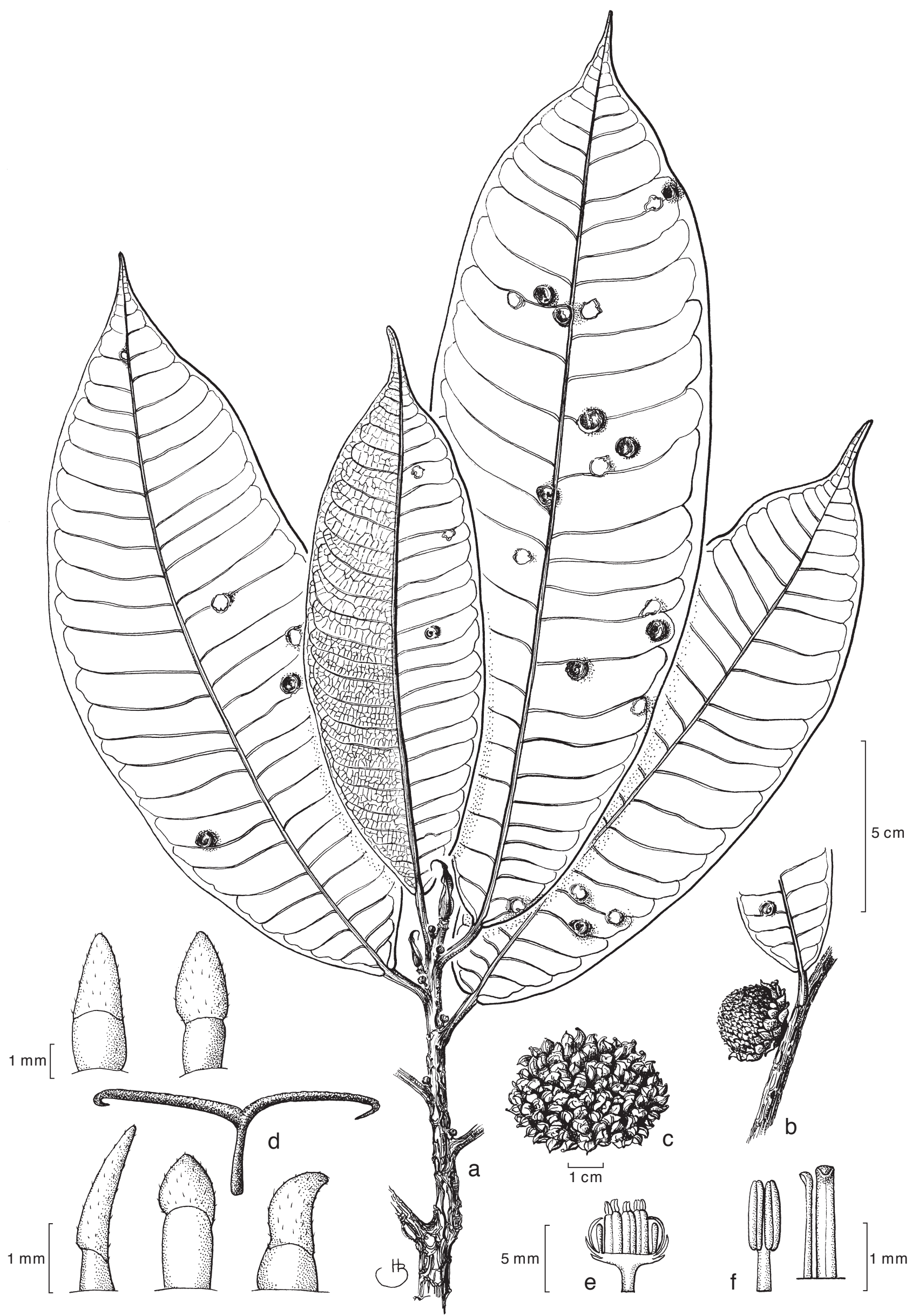

Fig. 3 Naucleopsis francisci C.C.Berg \& Homelier. a. Leafy twig with fungus-infected leaves and (young) staminate inflorescences; b. pistillate inflorescence; c. surface of infructescence; $d$. free apices of tepals of pistillate inflorescence and style with stigmas; e. staminate inflorescence in section; f. stamen and tepals (a, e, f: Homelier 2507; b, c: Quizhpe et al. 740; all BG). — Drawing by Hendrieke Berg (Nos). 
lower surface glabrous; lateral veins 23-27 pairs, the lower ones weakly developed and weakly loop-connected, tertiary venation reticulate; petiole $0.5-1.5 \mathrm{~cm}$ long, $2-2.5 \mathrm{~mm}$ thick, glabrous, the epidermis flaking off; stipules $1-2 \mathrm{~cm}$ long, often \pm curved, whitish-puberulous. Staminate inflorescences axillary or just below the leaves, solitary, in pairs or in clusters of 3 (on minute short shoots), peduncle $0.2-0.3 \mathrm{~cm}$ long, ebracteate; receptacle c. $0.5 \mathrm{~cm}$ diam; involucre with $3-4$ series of semicircular to suborbicular bracts: flowers c. 15-20, tepals 3-4, 1-2 mm long, \pm culculate; stamens 2 or 3 , anthers c. $5 \mathrm{~mm}$ long. Pistillate inflorescences axillary or just below the leaves, c. 2.5 $\mathrm{cm}$ diam; peduncle $0.1-0.3 \mathrm{~cm}$ long; involucral bracts in 6-7 series, semicircular to oblong, sparsely minutely puberulous, the apex rounded; flowers numerous, free parts of the tepals $1.5-2.5 \mathrm{~mm}$ long, variously shaped; stigmata c. $2 \mathrm{~mm}$ long. Infructescences c. $5 \mathrm{~cm}$ diam, free parts of the tepals subpyramidate, to $0.5 \mathrm{~cm}$ long.

Distribution - This species is only known from Ecuador, Zamora-Chinchipe, in montane forest, at 1800-2150 m.

Notes - 1. The type collection has been listed among unnamed Naucleopsis collections in Berg 2001 (p. 289).

2. This species shows similarities to Naucleopsis ulei (Warb.) Ducke, in particular subsp. amara (Ducke) C.C.Berg because of the weakly loop-connected lower lateral veins of the lamina. It differs from N. ulei in the much shorter free parts of the tepals at fruit. Moreover, $N$. ulei is not affected by fungi as this new species which is also clearly a montane species in contrast to N. ulei (Berg 2001).

3. The fact that the leaves on the lateral branches, also fertile ones, are often arranged in lax spirals, the trees may not fully exhibit the features of the model of Cook, as characteristic for the tribe (Berg 1977).
4. The lamina is infected by a fungus causing circular warty spots becoming holes, like in N. krukovii (Standl.) C.C.Berg (Berg 1972).

Additional specimens examined. EcUADOR, W. Quizhpe et al. 740 (BG), Zamora-Chinchipe, Cordillera del Cóndor, San Carlos de Las Minas, Nambija, 2100 m, 25 Jan. 2005 (female fl); J. Homeier 390 (BG, MO, QCNE) and J. Homeier 2570 (BG, GOET MO, QCNE), Zamora-Chinchipe, road Loja-Zamora, c. km 35, Estacion Cientifica San Francisco, 1800 m, 9 Apr. 2000 (st), and 2120 m, 6 May 2007 (male), respectively.

Acknowledgements The diagnoses were translated into Latin by Dr. J.F. Veldkamp (Leiden). The preparation of the drawings was financed by the Olaf Grolle Olsen Foundation of the University of Bergen. The illustrations were drawn by Hendrieke Berg (Voss).

\section{REFERENCES}

Berg CC. 1972. Olmedieae, Brosimae (Moraceae). Flora Neotropica Monograph No. 7. Hafner Publishing Company, New York.

Berg CC. 1977. The Castilleae, a tribe of the Moraceae, renamed and redefined due to the exclusion of the type genus Olmedia from the 'Olmedieae'. Acta botanica neerlandica 26: 73-82.

Berg CC. 1999. A new species of Ficus (Moraceae) from Bolivia and Peru. Brittonia 51, 3: 395-397.

Berg CC. 2001. Flora Neotropica Monograph 83: Moreae, Artocarpeae, Dorstenia (Moraceae). With introductions to the family and Ficus and with additions and corrections to Flora Neotropica Monograph 7. The New York Botanical Garden, Bronx, New York

Berg CC, Villavicencio X. 2003. El género Ficus en Bolivia. Revista de la Sociedad Boliviana de Botánica 4, 1: 81-129.

Berg CC, Villavicencio X. 2004. Taxonomic studies on Ficus (Moraceae) in the West Indies, extra-Amazonian Brazil, and Bolivia. Ilicifolia 5: 1-132, t. $1-45$. 